\title{
European Guidelines for Obesity Management in Adults
}

\author{
Volkan Yumuk $^{\mathrm{a}}$ Constantine Tsigos $^{\mathrm{b}}$ Martin Fried $^{\mathrm{c}}$ \\ Karin Schindler ${ }^{d}$ Luca Busetto $^{e}$ Dragan Micic $^{f}$ \\ Hermann Toplakg for the Obesity Management Task Force of \\ the European Association for the Study of Obesity
}

\begin{abstract}
a Division of Endocrinology, Metabolism and Diabetes, Department of Medicine, Istanbul University Cerrahpasa Medical Faculty, Istanbul, Turkey; ${ }^{b}$ Department of Nutrition and Dietetics, Harokopio University, Athens, Greece; ${ }^{c}$ Clinical Center for Minimally Invasive and Bariatric Surgery, ISCARE Lighthouse, Prague and 1st Medical Faculty, Charles University, Prague, Czech Republic; ${ }^{d}$ Department of Medicine III, Medical University of Vienna,

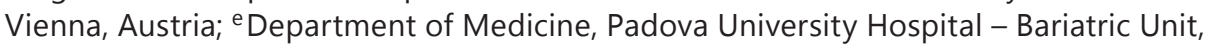
University of Padova, Padova, Italy; ${ }^{f}$ Centre for Metabolic Disorders in Endocrinology, Institute of Endocrinology, Diabetes and Diseases of Metabolism, Clinical Center of Serbia, Belgrade, Serbia; 9 Department of Medicine, Institute for Diabetes and Metabolism, Medical University, Graz, Austria
\end{abstract}

\section{Key Words}

European guidelines · Obesity management $\cdot$ Multidisciplinary $\cdot$ Primary care $\cdot$ OMTF $\cdot$ COMs

\begin{abstract}
Obesity is a chronic metabolic disease characterised by an increase of body fat stores. It is a gateway to ill health, and it has become one of the leading causes of disability and death, affecting not only adults but also children and adolescents worldwide. In clinical practice, the body fatness is estimated by BMI, and the accumulation of intra-abdominal fat (marker for higher metabolic and cardiovascular disease risk) can be assessed by waist circumference. Complex interactions between biological, behavioural, social and environmental factors are involved in regulation of energy balance and fat stores. A comprehensive history, physical examination and laboratory assessment relevant to the patient's obesity should be obtained. Appropriate goals of weight management emphasise realistic weight loss to achieve a reduction in health risks and should include promotion of weight loss, maintenance and prevention of weight regain. Management of co-morbidities and improving quality of life of obese patients are also included in treatment aims. Balanced hypocaloric diets result in clinically meaningful weight loss regardless of which macronutrients they emphasise. Aerobic training is the optimal mode of exercise for reducing fat mass while a programme including resistance train-
\end{abstract}


ing is needed for increasing lean mass in middle-aged and overweight/obese individuals. Cognitive behavioural therapy directly addresses behaviours that require change for successful weight loss and weight loss maintenance. Pharmacotherapy can help patients to maintain compliance and ameliorate obesity-related health risks. Surgery is the most effective treatment for morbid obesity in terms of long-term weight loss. A comprehensive obesity management can only be accomplished by a multidisciplinary obesity management team. We conclude that physicians have a responsibility to recognise obesity as a disease and help obese patients with appropriate prevention and treatment. Treatment should be based on good clinical care, and evidence-based interventions; should focus on realistic goals and lifelong multidisciplinary management.

(c) 2015 S. Karger $\mathrm{GmbH}$, Freiburg

\section{Introduction}

Obesity is a metabolic disease (ICD-10 code E66) that has reached epidemic proportions. The World Health Organization (WHO) has declared obesity as the largest global chronic health problem in adults which is increasingly turning into a more serious problem than malnutrition. Obesity is a gateway to ill health, and it has become one of the leading causes of disability and death, affecting not only adults but also children and adolescents worldwide [1]. In 2014, more than 1.9 billion adults (18 years and older) were overweight. Of these over 600 million were obese. 42 million children under the age of 5 were overweight or obese in 2013 [2]. The WHO world health statistics report in 2015 shows that in the European region the overall obesity rate among adults is $21.5 \%$ in males and $24.5 \%$ in females (fig. 1 ). The same report states that the prevalence for overweight among children under the age of 5 is $12.4 \%$ [3]. It has been further projected that $60 \%$ of the world's population, i.e. 3.3 billion people, could be overweight (2.2 billion) or obese (1.1 billion) by 2030 if recent trends continue [4]. Obesity has important consequences for morbidity, disability and quality of life and entails a higher risk of developing type 2 diabetes, cardiovascular diseases, several common forms of cancer, osteoarthritis and other health problems [5]. In 2010, overweight and obesity were estimated to cause 3.4 million deaths, $4 \%$ of years of life lost, and $4 \%$ of disability-adjusted life years (DALYs) [6].

\section{Definition and Classification}

Obesity is a chronic disease characterised by an increase of body fat stores. In clinical practice, the body fatness is usually estimated by BMI. BMI is calculated as measured body weight $(\mathrm{kg})$ divided by measured height squared $\left(\mathrm{m}^{2}\right)$. In adults (age over 18 years) obesity is defined by a BMI $30 \mathrm{~kg} / \mathrm{m}^{2}$ and overweight (also termed pre-obesity) by a BMI between 25 and $29.9 \mathrm{~kg} / \mathrm{m}^{2}$. Lower BMI cut-off points apply for some ethnic groups (e.g. Southeast Asians) $[7,8]$ (table 1) \{level 1\}. Accumulation of intra-abdominal fat is associated with higher metabolic and cardiovascular disease risk [7, 9] \{level 1\}. The amount of abdominal fat can be assessed by waist circumference (WC) which highly correlates with intra-abdominal fat content. The WC is measured in the horizontal plane midway in the distance of the superior iliac crest and the lower margin of the last rib. The most recent International Diabetes Federation (IDF) consensus defined central obesity (also known as visceral, android, apple-shaped or upper body obesity) in Europids as a WC of $\geq 94 \mathrm{~cm}$ in men and $\geq 80 \mathrm{~cm}$ in non-pregnant women. Lower cut-off points for central obesity are proposed for different ethnic groups [10] $\{$ level 4\}. 
Yumuk et al.: European Guidelines for Obesity Management in Adults

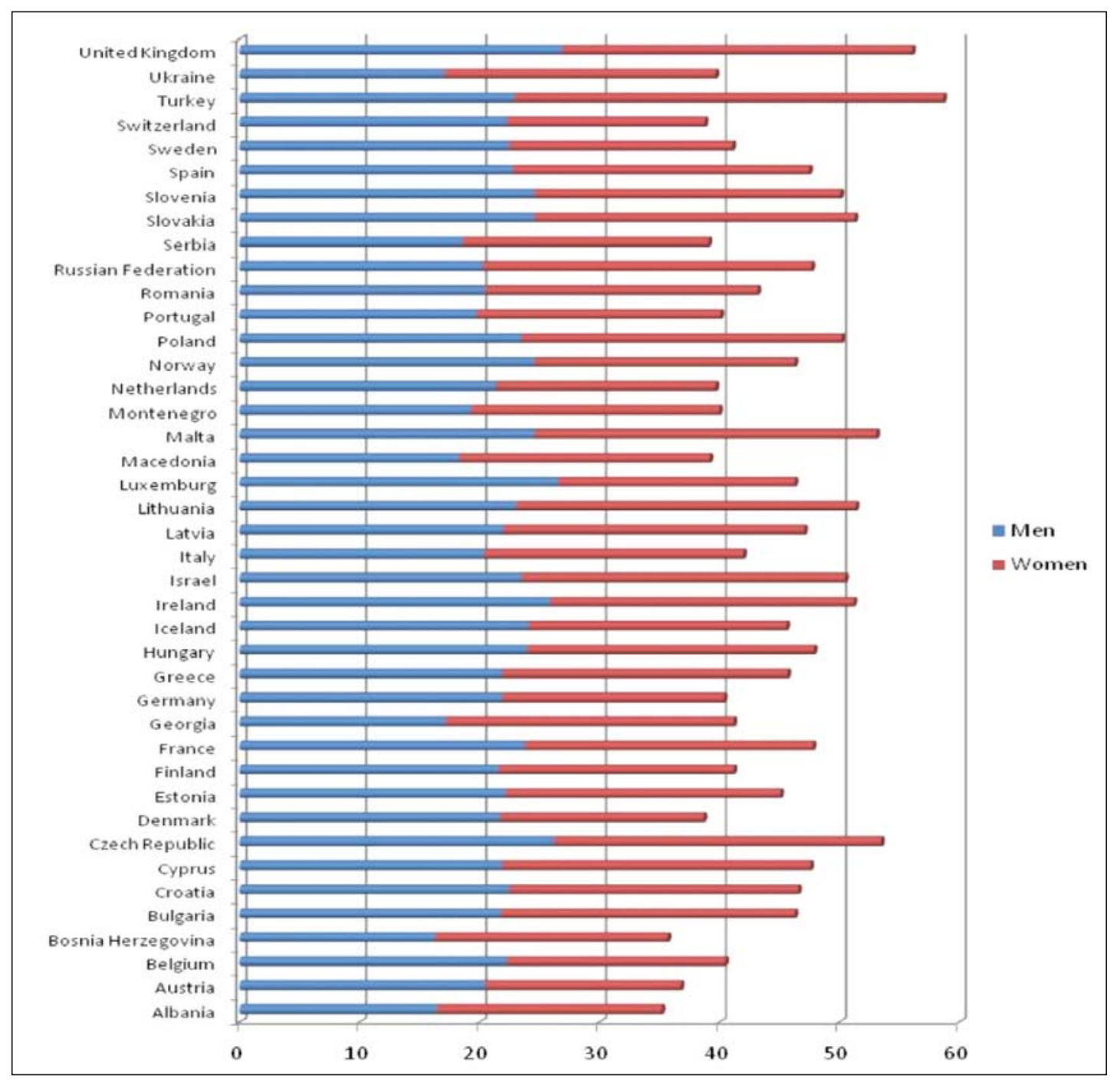

Fig. 1. Obesity prevalence in adults in Europe (Source: WHO 2014 data).

Table 1. BMI categories (WHO 1997)

\begin{tabular}{ll}
\hline Category & $\mathrm{BMI}, \mathrm{kg} / \mathrm{m}^{2}$ \\
\hline Underweight & $<18.5$ \\
Healthy weight & $18.5-24.9$ \\
Pre-obese state & $25.0-29.9$ \\
Obesity grade I & $30.0-34.9$ \\
Obesity grade II & $35.0-39.9$ \\
Obesity grade III & $\geq 40$ \\
\hline
\end{tabular}

\section{Pathogenesis of Obesity}

The cause of obesity is complex and multifactorial $[11,12]$. At the simplest level, obesity develops as a result of a period of chronic energy imbalance and is maintained by a continued elevated energy intake sufficient to maintain the acquired higher energy needs of the obese state. Complex interactions between biological (including genetic and epigenetic), behav- 
ioural, social and environmental factors (including chronic stress) are involved in regulation of energy balance and fat stores $[13,14]$. The rapid increase in the prevalence of obesity over the past 30 years is mainly a result of cultural and environmental influences. High energy density diet, increased portion size, low physical activity and adoption of a sedentary lifestyle as well as eating disorders are considered as important risk factors for the development of obesity $[8,15]$. These behavioural and environmental factors lead to alterations in adipose tissue structure (hypertrophy and hyperplasia of adipocytes, inflammation) and secretion (e.g. adipokines) $[16,17]$. Weight loss surgery has proven to be a convenient and proper research tool facilitating insights into the pathogenesis of obesity as well as regulation of hunger and satiation. Gut hormones communicate information from the gastrointestinal tract to the regulatory appetite centres within the CNS via the so-called 'gut-brain axis' $[18,19]$. Obesity is associated with changes in the composition of the intestinal microbiota. Products of intestinal microbes may induce beneficial metabolic effects through enhancement of mitochondrial activity, prevention of metabolic endotoxaemia and activation of intestinal gluconeogenesis via different routes of gene expression and hormone regulation [20,21]. The role of thermogenesis of brown adipose tissue and its contribution to energy expenditure is being investigated mainly to develop strategies to recruit and activate energy-dissipating brown adipose tissue as a preventive or remedial measure for weight control in obesity [22-24].

\section{Clinical Evaluation of the Obese Patient}

A comprehensive history, physical examination and laboratory assessment relevant to the patient's obesity should be obtained [25-27] \{Recommended Best Practice (RBP)\}.

\section{History Taking}

- Ethnicity

- Family history

- Dietary habits

- Physical activity frequency and nature

- $\quad$ Eating pattern and possible presence of an eating disorder (binge eating disorder, night eating syndrome, bulimia)

- Presence of depression and other mood disorders

- Other determinants, e.g., genetic, drugs, endocrine abnormalities, psychosocial factors, chronic stress, smoking cessation etc.

- Health consequences of obesity (table 2)

- Patient expectations and motivation for change

- Previous treatments for obesity.

\section{Physical Examination}

- Measure weight and height (from which BMI is calculated), WC, blood pressure (appropriate size cuff) \{grade 3\}

- Assess the presence and impact of obesity-related diseases (diabetes, hypertension, dyslipidaemia; cardiovascular, respiratory and joint diseases; non-alcoholic fatty liver disease (NAFLD), sleep disorders etc.) $\{$ RBP $\}$

- Look for the presence of acanthosis nigricans as a sign of insulin resistance $\{R B P\}$. 
Yumuk et al.: European Guidelines for Obesity Management in Adults

Table 2. A guide to deciding the initial level of intervention to discuss with the patient

\begin{tabular}{llll}
\hline BMI, $\mathrm{kg} / \mathrm{m}^{2 *}$ & WC, $\mathrm{cm}^{*}$ & \multicolumn{2}{c}{ Co-morbidities } \\
\cline { 2 - 3 } & $\begin{array}{l}\text { men }<94, \\
\text { women }<80\end{array}$ & $\begin{array}{l}\text { men } \geq 94, \text { women } \\
\end{array}$ & \\
\hline $25.0-29.9$ & $\mathrm{~L}$ & $\mathrm{~L}$ & \\
$30.0-34.9$ & $\mathrm{~L}$ & $\mathrm{~L} \pm \mathrm{D}$ & $\mathrm{L} \pm \mathrm{D}$ \\
$35.0-39.9$ & $\mathrm{~L} \pm \mathrm{D}$ & $\mathrm{L} \pm \mathrm{D}$ & $\mathrm{L} \pm \mathrm{D} \pm \mathrm{S}^{* *}$ \\
$\geq 40.0$ & $\mathrm{~L} \pm \mathrm{D} \pm \mathrm{S}$ & $\mathrm{L} \pm \mathrm{D} \pm \mathrm{S}$ & $\mathrm{L} \pm \mathrm{D} \pm \mathrm{S}$ \\
&
\end{tabular}

$\mathrm{L}=$ Lifestyle intervention (diet and physical activity); $\mathrm{D}=$ consider drugs; $\mathrm{S}=$ consider surgery.

*BMI and waist circumference cut-off points are different for some ethnic groups.

**Patients with type 2 diabetes on individual basis.

\section{Laboratory Examinations}

The minimum data set required will include $\{\mathrm{RBP}\}$ :

- Fasting blood glucose

- Serum lipid profile (total, HDL and LDL cholesterol, triglycerides)

- Uric acid

- Thyroid function (thyroid-stimulating hormone (TSH) level)

- $\quad$ Liver function (hepatic enzymes)

- Cardiovascular assessment, if indicated $\{\mathrm{RBP}\}$

- Endocrine evaluation if Cushing's syndrome or hypothalamic disease suspected

- Liver investigation (ultrasound, biopsy) if abnormal liver function tests suggest NAFLD or other liver pathology

- Sleep laboratory investigation for sleep apnoea.

\section{Body Composition Analysis}

WC can be used as a proxy for abdominal fat [9] \{level 3; RBP\}. With the development of devices and equipment to more accurately measure body fat, including dual energy X-ray absorptiometry (DEXA), air-displacement plethysmography (BodPod), bioimpedance analysis (BIA) and body scanning procedures - replacing the cumbersome underwater weighing -, it has become possible to more easily classify individuals according to the degree of body fat, independently of BMI. This approach has also drawn attention to the function of non-adipose tissue - that is, fat-free mass (FFM) or lean mass - and the contribution made by FFM to physiological functioning, pathology and well-being [28-30]. Assessment of body composition is not essential for the management of obesity in routine clinical practice, but may be a useful tool in measuring fat and FFM before and during treatment $\{\mathrm{RBP}$.

\section{Comprehensive Obesity Management}

Appropriate goals of weight management emphasise realistic weight loss to achieve a reduction in health risks and should include promotion of weight loss, maintenance and prevention of weight regain (fig. 2) \{RBP\}. Patients should understand that, since obesity is a chronic disease, weight management will need to be continued lifelong. 


\section{Clinical care pathway for overweight and obese adults}

Determine degree of overweight and obesity

- Measure height $(\mathrm{cm})$ and weight $(\mathrm{kg})$ and calculate BMI $\left(\mathrm{kg} / \mathrm{m}^{2}\right)$

- Measure waist circumference (WC) $\mathrm{cm}$

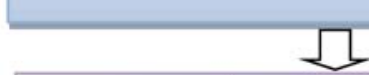

If $\mathrm{BMI} \geq 25 \mathrm{~kg} / \mathrm{m}^{2} *$

or WC $\geq 94 \mathrm{~cm}$ for men*

or WC $\geq 80 \mathrm{~cm}$ for women*

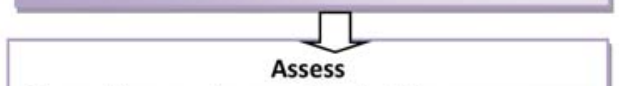

Presenting symptoms and underlying causes

Co-morbidities and health risks

Weight loss history

Lifestyle (nutrition and physical activity)

Eating behaviour

Depression and mood disorders

Chronic psychological stress

Potential of weight loss to improve health

Motivation to change

Barriers to weight loss

\section{$\square$}

Set goals and propose realistic, individualised and sustainable lifestyle changes at the long term Weight loss goal

$5-15 \%$ of body weight or $0.5-1.0 \mathrm{~kg} /$ week

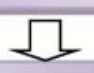

\section{Management}

Nutrition

Reduce energy intake by $500-1,000 \mathrm{kcal} /$ day Physical activity

Initially at least $150 \mathrm{~min} /$ week moderate aerobic exercise combined with $1-3$ sessions/week resistance exercise

Cognitive behaviour therapy

Pharmacotherapy

$\mathrm{BMI} \geq 30 \mathrm{~kg} / \mathrm{m}^{2}$ or $\mathrm{BMI} \geq 27 \mathrm{~kg} / \mathrm{m}^{2}$ with co-

morbidities

Adjunct to lifestyle modification

Bariatric/metabolic surgery

$B M I \geq 40 \mathrm{~kg} / \mathrm{m}^{2}$ or BMI between $35.0-39.9 \mathrm{~kg} / \mathrm{m}^{2}+$ co-morbidities or BMI between $30.0-34.9 \mathrm{~kg} / \mathrm{m}^{2}$

with type 2 diabetes on individual basis. Consider

if other weight loss attempts fail; requires lifelong

medical monitoring

Prevention and treatment of co-morbidities
Considering referring to obesity specialist services or Collaborating Centres for Obesity

\section{Management (COMs)}

- If the person has complex disease states or needs that can not be managed in primary or secondary care

- If the underlying causes of obesity need to be assessed

- If conventional treatment has failed

- If specialist interventions such as VLCD is needed

- If bariatric/metabolic surgery is needed

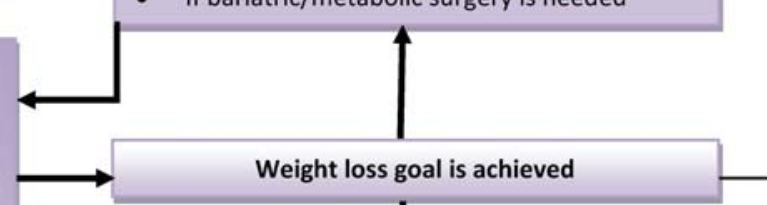

Fig. 2. Algorithm for the assessment and stepwise management of overweight and obese adults. *BMI and WC cut-off points are different for some ethnic groups (see text).
Assess effect on co-morbidities, weight

maintenance and weight regain

- Regular monitorng of weight, BMI and WC

- Reinforce lifestyle modification

- Address other risk factors 


\section{Aims of Treatment}

The management and treatment of obesity (fig. 2) have wider objectives than weight loss alone and include risk reduction and health improvement. Significant clinical benefits may be achieved even by modest weight loss (i.e. $5-10 \%$ of initial body weight), and lifestyle modification (improved nutritional content of the diet and modest increases in physical activity and fitness) [31-34] \{level 1\}. Obesity management cannot focus only on weight (and BMI) reduction. More attention is to be paid to $\mathrm{WC}$ and the improvement in body composition which is focusing on ameliorating or maintaining FFM and decreasing fat mass [35].

Management of co-morbidities, improving quality of life and well-being of obese patients are also included in treatment aims. Appropriate management of obesity complications in addition to weight management should include management of dyslipidaemia, optimising glycaemic control in type 2 diabetic patients, normalising blood pressure in hypertension, management of pulmonary disorders such as sleep apnoea syndrome (SAS), attention to pain control and mobility needs in osteoarthritis, management of psychosocial disturbances including affective disorders, eating disorders, low self-esteem and body image disturbance. Obesity management may reduce the need to treat co-morbidities by drugs [36-38] \{level 1; grade A\}.

\section{Prevention of Further Weight Gain}

In overweight patients (BMI $25.0-29.9 \mathrm{~kg} / \mathrm{m}^{2}$ ) without overt co-morbidities, prevention of further weight gain (through dietary advice and increase in physical activity) rather than weight loss per se may be an appropriate target. Weight loss objectives should be realistic, individualised and aimed at the long term (table 3 ) \{RBP $\}$.

\section{Practical Weight Loss Objectives}

A 5-15\% weight loss over a period of 6 months is realistic and of proven health benefit $[39,40]$ level 1$\}$. A greater (20\% or more) weight loss may be considered for those with greater degrees of obesity (BMI $\left.\geq 35 \mathrm{~kg} / \mathrm{m}^{2}\right)\{\mathrm{RBP}\}$. Maintenance of weight loss and prevention and treatment of co-morbidities are the two main criteria for success.

\section{Failure to Lose and Maintain Weight}

Referral to an obesity specialist (or an obesity management team) should be considered if the patient fails to lose weight in response to the prescribed intervention (fig. 2). Weight cycling, defined by repeated loss and regain of body weight, is more frequent in women and may be linked to increased risk for hypertension, dyslipidaemia and gallbladder disease [41]. It has been associated with psychological distress and depression and may require appropriate psychological care and/or antidepressant therapy [42].

\section{Patient Follow-Up}

Obesity is a chronic disease. A follow-up and continued supervision is necessary [43] to prevent weight regain \{level 2\}, and to monitor disease risks and treat co-morbidities (e.g. type 2 diabetes mellitus, cardiovascular disease) $\{\mathrm{RBP}\}$. 


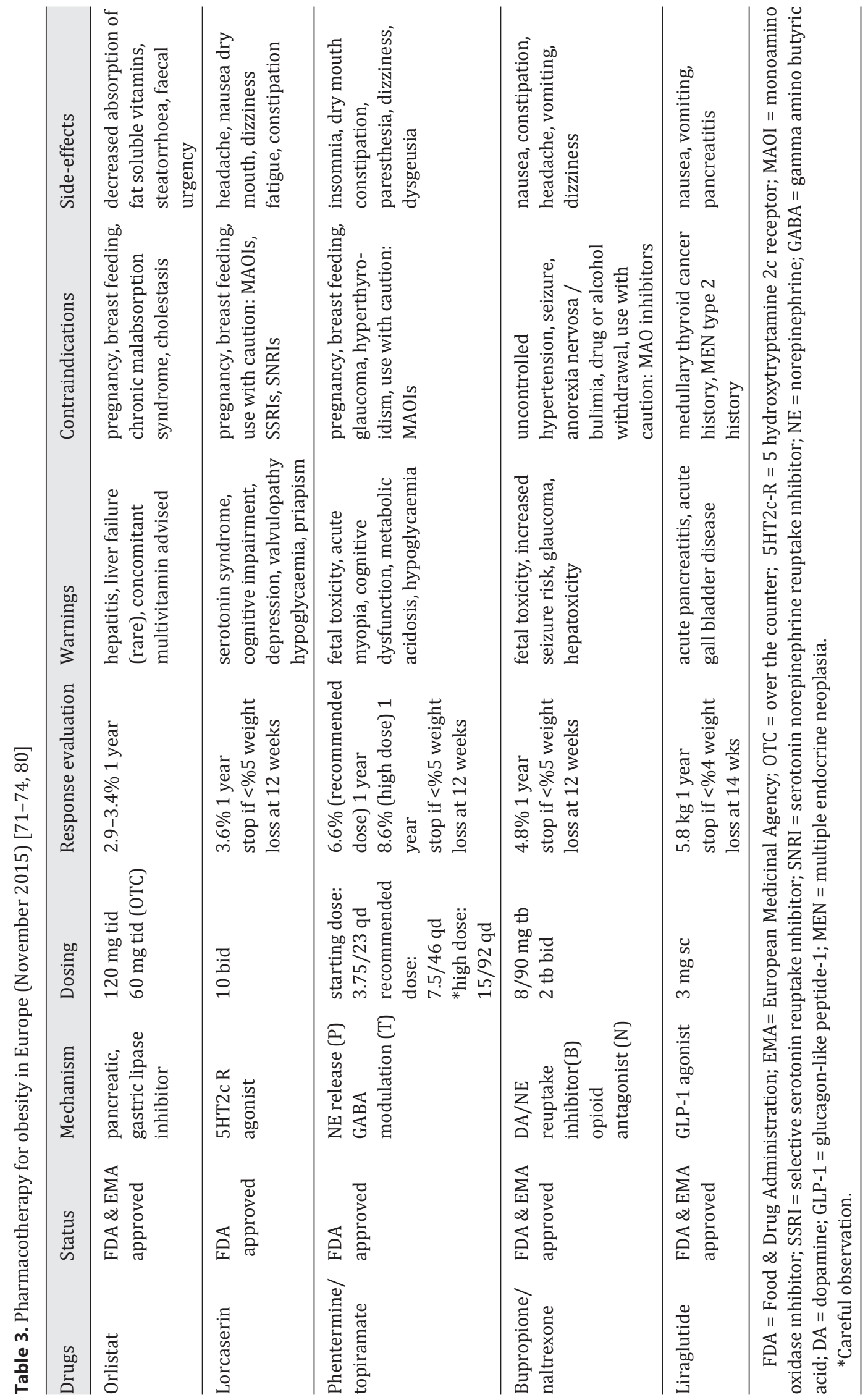


Yumuk et al.: European Guidelines for Obesity Management in Adults

\section{Specific Components of Treatment}

\section{Nutrition and Dieting}

The use of self-recorded food diary allows a qualitative assessment of the diet. In addition, it can be used to help the patient identify meal frequency (night eating, snacking, meal skipping) perceptions and beliefs about emotional eating behaviour (cognition), eating habits (behaviour) and environmental challenges to following a healthy diet $\{\mathrm{RBP}$.

Before giving dietary advice it might be useful to address motivation for change: How important is weight loss for the patients, and how confident the individual patient is to successfully and sustainably achieve body weight reduction $[44,45]$ ? Dietary advice should encourage healthy eating and emphasise the need to increase consumption of vegetables, beans, legumes, lentils, grain, unsweetened cereals and fibre, and to substitute low-fat dairy products and meats for high-fat alternatives. It should also emphasise increased intake of seafood. It is recommended to avoid foods containing added sugars and solid fats, as well as consumption of sugary drinks and alcohol-containing beverages [37, 46-48] \{level 1, 2\}. An appropriate dietary regimen can be achieved in a number of ways:

\section{General Advice \{level 3, 4\}}

- Decrease energy density of foods and drinks

- Decrease the size of food portions

- Avoid snacking between meals

- $\quad$ Do not skip breakfast and avoid eating in the night time

- Manage and reduce episodes of loss of control or binge eating.

\section{Specific Advice}

Energy (calorie) restriction should be individualised and take account of nutritional habits, physical activity, co-morbidities and previous dieting attempts. Prescribing an energy-restricted diet may require the intervention of a nutritionist (dietitian) \{RBP\}. Balanced hypocaloric diets result in clinically meaningful weight loss regardless of which macronutrients they emphasise. An emphasis put on the macronutrient proportion in the various diets (low fat, low carbohydrate or high protein etc.) has not proved better than a balanced hypocaloric diet, except for low-glycaemic load diets (carbohydrate content of the diet $\times$ glycaemic index) in the short term [49-51] \{level 1\}. Despite various ranges of macronutrient composition, these diets have beneficial effects on reducing risk factors for cardiovascular disease and type 2 diabetes as well as on promoting adherence, diet acceptability and sustainability, satiety and satisfaction. Balanced hypocaloric diets can be tailored to individual patients on the basis of their personal and cultural preferences and may therefore have the best chance for long-term success (e.g. Mediterranean diet) [52, 53].

A $15-30 \%$ decrease in energy (calorie) intake from habitual intake in a weight-stable individual is sufficient and appropriate. However, underreporting of energy intake by obese patients is common. There is a great variation in energy requirements between the individuals which is dependent on the individual's gender, age, BMI and physical activity level. Tables predicting energy requirements taking into account gender, age, BMI and physical activity ratio can be used. An easy rule of thumb is a daily energy requirement of $25 \mathrm{kcal} / \mathrm{kg}$ for either gender but, for the same body weight, this creates a greater energy deficit in men. The recommended weight-reducing dietary regimen tailored to an individual's need usually provides an energy deficit of $600 \mathrm{kcal} /$ day grade A, B . A $600 \mathrm{kcal}(2,600 \mathrm{~kJ})$ daily deficit will predict a weight loss of about $0.5 \mathrm{~kg}$ weekly. Thus for an obese sedentary woman with a BMI 
of $32 \mathrm{~kg} / \mathrm{m}^{2}$ and with an estimated daily intake of 2,100 kcal (8,800 kJ), a diet prescribing $1,400-1,600 \mathrm{kcal}(6,000-7,000 \mathrm{~kJ})$ would be appropriate $[50,54]$ level 2$\}$.

Diets providing $1,200 \mathrm{kcal} /$ day or more are classified as hypocaloric balanced diets (HBD) or balanced deficit diets [51]. Diets providing less than 1,200 kcal/day might yield micronutrient deficiencies, which could exert untoward effects not only on nutritional status but also on the weight management outcome. However in clinical practice a further reduction in caloric intake might be required. In this case the appropriate use of dietary supplements may prevent such nutritional deficits. In clinical practice low-calorie diets (LCDs) and very-low-calorie diets (VLCDs) are used. LCDs, consisting of normal meals and partial meal replacements, have an energy content between 800 and $1,200 \mathrm{kcal} /$ day. VLCDs usually provide less than 800 $\mathrm{kcal} /$ day and may be used only as part of a comprehensive programme under the supervision of an obesity specialist or another physician trained in nutrition and dietetics. Their administration should belimited for specific patients and for short periods of time. VLCDs are unsuitable as a sole source of nutrition for children and adolescents, pregnant or lactating women and the elderly. Meal replacement diets (substitution of one or two daily meal portions by VLCD) may contribute to nutritionally well-balanced diet and weight loss maintenance [55-59] \{level 2\}.

\section{Physical Activity}

Exercise is considered an important component of a weight reduction programme in conjunction with caloric reduction. Several studies report additive benefits of combining exercise with caloric restriction on reducing body weight and body fat and preservation of FFM as compared to diet alone. In balancing time commitments against health benefits, it appears that aerobic training is the optimal mode of exercise for reducing fat mass and body mass while a programme including resistance training is needed for increasing lean mass in middle-aged and overweight/obese individuals $[60,61]$ \{level 1 ; grade B $\}$. However, if we limit the discussion to the outcome 'weight loss' or 'fat mass loss', only aerobic exercise has solid evidence supporting its efficacy in the literature. There is enough evidence which suggests that aerobic and resistance exercises are beneficial for patients with obesity and related morbidities. For this reason, all scientific guidelines recommend that at least $150 \mathrm{~min} /$ week of moderate aerobic exercise (such as brisk walking) should be combined with three weekly sessions of resistance exercise to increase muscle strength [60-62] \{level 2; grade B\}.

Increasing physical activity reduces intra-abdominal fat and increases lean (muscle and bone) mass \{level 2\}, while it attenuates the weight loss-induced decline of resting energy expenditure \{level 2$\}$, reduces blood pressure, improves glucose tolerance, insulin sensitivity, lipid profile and physical fitness \{level 1$\}$, ameliorates compliance to the dietary regimen, has a positive influence on the long-term weight maintenance \{level 2\}, improves feeling of wellbeing and self-esteem \{level 2\}, and reduces anxiety and depression \{level 2\} [63-65]. Further objectives should be to reduce sedentary behaviour (e.g. television viewing and computer use) and increase daily activities (e.g. walking or cycling instead of using a car, climbing stairs instead of using elevators). Patients should be advised and helped in undertaking (or increasing) physical activity $[66,67]$ \{level 2; grade B\}. Exercise advice must be tailored to the patient's ability and health and focus on a gradual increase to levels that are safe $\{R B P\}$.

\section{Cognitive Behavioural Therapy}

Cognitive Behavioural Therapy (CBT) is a blend of cognitive therapy and behavioural therapy and aims to help a patient modify his/her insight and understanding of thoughts and 
Yumuk et al.: European Guidelines for Obesity Management in Adults

beliefs concerning weight regulation, obesity and its consequences; it also directly addresses behaviours that require change for successful weight loss and weight loss maintenance. CBT includes several components such as self-monitoring (e.g. dietary record), techniques controlling the process of eating, stimulus control and re-enforcement as well as cognitive and relaxation techniques. CBT elements should form part of routine dietary management or, as a structured programme, form the basis of specialist intervention \{grade B\}. This care can be in part delivered in a group setting or using self-help manuals [68-70]. CBT can be provided not only by registered psychologists but also by other trained health professionals such as physicians, dieticians, exercise physiologists or psychiatrists $\{\mathrm{RBP}\}$.

\section{Psychological Support}

Physicians should recognise where psychological or psychiatric issues interfere with successful obesity management, e.g. depression. Psychological support and/or treatment will then form an integral part of management; in special cases (anxiety, depression and stress), referral to a specialist may be indicated. Self-help lay groups and the support of the obesity treatment group may all be useful in this setting $\{$ RBP $\}$.

\section{Pharmacological Treatment}

Pharmacological treatment should be considered as part of a comprehensive strategy of disease management $[37,71]$ \{grade A\}. Pharmacotherapy can help patients to maintain compliance, ameliorate obesity-related health risks and improve quality of life. It can also help to prevent the development of obesity co-morbidities (e.g. type 2 diabetes mellitus). Current drug therapy is recommended for patients with a BMI $\geq 30 \mathrm{~kg} / \mathrm{m}^{2}$ or a BMI $\geq 27$ $\mathrm{kg} / \mathrm{m}^{2}$ with an obesity-related disease (e.g. hypertension, type 2 diabetes mellitus, sleep apnoea) [37] (table 2) \{RBP\}. Drugs should be used according to their licensed indications and restrictions $\{\mathrm{RBP}\}$. The efficacy of pharmacotherapy should be evaluated after the first 3 months. If weight loss achieved is satisfactory $(>5 \%$ weight loss in non-diabetic and $>3 \%$ in diabetic patients), treatment should be continued [37, 71-74] grade A\}. Treatment should be discontinued in non-responders (table 3 ) $\{\mathrm{RBP}\}$.

\section{Orlistat}

Orlistat is a potent and selective inhibitor of pancreatic lipase that reduces intestinal digestion of fat. The drug is available over the counter at a dose of $60 \mathrm{mg}$ and a prescription dosage of $120 \mathrm{mg}$. Both forms are given before each meal and produce a moderate absolute and placebo-subtracted weight loss [71-74]. The efficacy and safety of the drug were assessed in the following RCTs: XENDOS [75] and X-PERT [76]. Faecal fat loss and related gastrointestinal symptoms are common. It may causes small decreases in fat-soluble vitamins; thus a multivitamin can be prescribed [77].

\section{Lorcaserin}

Lorcaserin is a serotonin type $2 \mathrm{C}$ receptor agonist with hypophagic effects [78]. Lorcaserin has been available in the USA since June 2013. The recommended dose is $10 \mathrm{mg}$ twice daily. The product licence requires $5 \%$ weight loss after 12 weeks of treatment. If a patient does not reach this target, the drug should be discontinued [71-74, 79, 80]. The efficacy and safety of the drug were assessed in the following RCTs: BLOOM [81], BLOOM-DM [82] and BLOSSOM [83]. In the BLOOM-DM trial, both fasting blood glucose and haemoglobin A1C 
(HbA1c) levels were improved. No statistically significant differences in the incidence of cardiac valvulopathy between the placebo and lorcaserin groups were found [82, 84]. The most common adverse events associated with lorcaserin included blurred vision, dizziness, somnolence, headache, gastrointestinal disturbance and nausea. The results of the ongoing cardiovascular outcomes trial CAMELLIA TIMI 61 will determine the role of lorcaserin in primary prevention of diabetes in overweight/obese individuals and its use in the high-risk population of patients with established cardiovascular disease or multiple cardiovascular risk factors $[85,86]$.

\section{Phentermine/Topiramate}

Phentermine and extended-release topiramate (PHEN/TPM-ER) is based on the principle of a synergistic combination of two drugs at a lower dose to obtain efficacy with less toxicity. Phentermine is an atypical amphetamine analogue that suppresses appetite by norepinephrine agonism in the CNS. Topiramate is an atypical anticonvulsant drug previously evaluated as a potential anti-obesity drug after reports of weight loss occurring in epileptic patients taking this drug. The mechanisms by which topiramate induces a weight loss are unknown and may include carbonic anhydrase inhibition of taste or influences on GABA transmission, thus reducing appetite [87]. After approval by the Food and Drug Administration (FDA), the drug was launched in the USA in September 2012. The recommended dosage is $7.5 \mathrm{mg}$ phentermine / $46 \mathrm{mg}$ topiramate once a day. The product licence requires $5 \%$ weight loss after 12 weeks of treatment. If a patient does not reach this target, the drug should be discontinued [71-74]. The efficacy and safety of the drug were assessed in the following RCTs: EQUIP [88], CONQUER [89], SEQUEL [90] and EQUATE [91]. Adverse events associated with PHEN/TPM-ER treatment were dry mouth, constipation, insomnia, palpitations, dizziness, paraesthesia, disturbances in attention, metabolic acidosis and renal calculi, headache, dysgeusia (distortion of sense of taste), alopecia and hypokalaemia [71-74, 92]. The combination is contraindicated during pregnancy due to its teratogenic potential. The FORTRESS (Fetal Outcome RetrospectiveTopiRamate Exposure Study) has estimated that women taking this combination had a two times increased risk of giving birth to children with oral clefts when compared to non-users. Owing to this risk, the drug has been approved with a risk evaluation and mitigation strategy recommendation by the FDA [93].

\section{Bupropion/Naltrexone}

Bupropion/naltrexone combines two centrally acting medications that had already been approved. Bupropion is used for treating depression and to aid smoking cessation. It is a nonselective inhibitor of the dopamine and norepinephrine transporters. Naltrexone is an opioid receptor antagonist widely used to treat alcohol and opiate dependence syndromes. The anorectic effect of the bupropion/naltrexone combination is believed to result from activation of POMC neurons in the arcuate nucleus. POMC neurons release a melanocyte stimulating hormone ( $\alpha$-MSH), which is a potent anorectic feeding neuropeptide, and these neurons project to other hypothalamic areas involved in feeding and body weight control. After approval by the FDA and the European Medicinal Agency (EMA), the drug is available in the USA since September 2012 and will be launched in Europe in approximately mid-2016. The recommended dosage is $16 \mathrm{mg}$ naltrexone / $180 \mathrm{mg}$ bupropion twice a day. The product licence requires $5 \%$ weight loss after 12 weeks of treatment. If a patient does not reach this target, the drug should be discontinued [71-74, 94]. The efficacy and safety of the drug were assessed in the following RCTs: COR-I [95], COR-II [96], COR-BMOD [97] and COR-DM [98]. The most common reported adverse event was nausea, which in most cases was transient for the first few weeks of treatment. Along with nausea, headache, dizziness, insomnia and 
Yumuk et al.: European Guidelines for Obesity Management in Adults

vomiting were the most common adverse events that led to discontinuation [94]. The Cardiovascular Outcomes Study of Naltrexone SR/Bupropion SR in Overweight and Obese Subjects with Cardiovascular Risk Factors (The Light Study) is still ongoing [99].

\section{Liraglutide}

Liraglutide is an injectable long-acting GLP-1R agonist designed to resist rapid metabolism by dipeptidyl peptidase-IV. While glucose-induced insulin release is stimulated, the glucagon response is reduced and appetite suppressed with additional effects on gastric emptying [100]. It has already successfully been introduced in type 2 diabetic patients (1.2-1.8 mg) once daily. After approval by the FDA and EMA, the drug (in a dosage of $3 \mathrm{mg}$ once daily) was launched for obesity treatment in the USA in November 2014 and in Europe in March 2015. The product licence requires 5\% weight loss after 12 weeks of treatment. If a patient does not reach this target, the drug should be discontinued [71-74, 101-104]. The efficacy and safety of the drug were assessed in the following RCTs: SCALE-Maintenance [105], SCALE-Obesity [106] and LEADER [107-109]. Liraglutide is generally well tolerated. Nausea and vomiting are the main, usually transient, side-effects, but they may actively contribute to weight loss [110].

\section{Bariatric and Metabolic Surgery}

Surgery is the most effective treatment for morbid obesity in terms of long-term weight loss, improvements of co-morbidities and quality of life and decreases of overall mortality [111-115]. A comprehensive overview of surgical treatment options for obesity and obesityrelated co-morbidities is provided in the Interdisciplinary European Guidelines on Metabolic and Bariatric Surgery, published in 2013 by joint effort of the European Association for the Study of Obesity (EASO), and the International Federation for the Surgery of Obesity and Metabolic Disorders - European Chapter (IFSO-EC) [116]. Surgery should be considered for patients aged 18-60 years with a BMI $\geq 40.0 \mathrm{~kg} / \mathrm{m}^{2}$ or with BMI between 35.0 and 39.9 $\mathrm{kg} / \mathrm{m}^{2}$ and co-morbidities, in whom surgically induced weight loss is expected to improve the disorder (such as type 2 diabetes and other metabolic disorders, cardiorespiratory disease, severe joint disease and obesity-related severe psychological problems). BMI criterion may be the current BMI or a documented previous BMI of this severity [117].

Bariatric surgery is clearly confirmed to be beneficial in type 2 diabetes remission - at least in the short and medium term. Thus, patients with BMI $>30$ and $<35 \mathrm{~kg} / \mathrm{m}^{2}$ with type 2 diabetes may also be considered for bariatric surgery on an individual basis, as there is evidence-based data supporting bariatric surgery benefits in regards to type 2 diabetes mellitus remission or improvement in this group [118-120] \{level 1\}.

Multidisciplinary skills are needed to support surgical interventions. Patients should only be referred to units able to assess patients prior to surgery, to offer a comprehensive approach to diagnosis, assessment and treatment, and to provide long-term follow-up. A decision to offer surgery should follow a comprehensive interdisciplinary assessment. The core team providing such assessment should optimally consist of the following specialists experienced in obesity management and bariatric surgery [121-123] \{level 2\}:

- Physician

- Surgeon

- Anaesthetist (anaesthesiologist)

- Psychologist or psychiatrist

- Nutritionist and/or dietitian, and

- Nurse practitioner/social worker. 
Table 4. Obesity-related health risks and complications

I. Metabolic complications

Diabetes

insulin resistance

Dyslipidaemia

Metabolic syndrome

Hyperuricaemia

Gout

Low-grade inflammation

II. Cardiovascular disorders

Hypertension

Coronary heart disease

Congestive heart failure

Stroke

Venous thromboembolism

III. Respiratory disease

Asthma

Hypoxemia

Sleep apnoea syndrome

Obesity hypoventilation syndrome

IV. Cancers

Oesophagus, small intestine, colon, rectum, liver, gallbladder, pancreas, kidney, leukaemia, multiple

myeloma, and lymphoma

In women: endometrial, cervix uteri, ovary, breast cancer after menopause

In men: prostate

V. Osteoarthritis

Knee and an increase in pain in the weight bearing joints

VI. Gastrointestinal

Gallbladder disease

Non-alcoholic fatty liver disease

Non-alcoholic steatohepatitis

Gastro-esophageal reflux

Hernia

Table 4 continued on next page

A laparoscopic technique should be considered as the first treatment choice in bariatric surgery. In all situations the bariatric surgeon's experience is a key issue for an immediate successful outcome. It is not advisable to perform bariatric techniques on an occasional basis [124] \{level 1\}. Morbid obesity is a lifelong disease. The treating physician and surgeon are responsible for the treatment of co-morbidities before the operation and for the follow-up after the operation. However, the patient takes lifelong responsibility for adhering to the follow-up rules $\{\mathrm{RBP}\}$.

In the past several years, better understanding of substantial metabolic changes induced by different surgical interventions to the alimentary tract was achieved. Therefore, the former classification of operations according to their influence on food ingestion, defined as limiting stomach capacity (restrictive), limiting absorption of nutrients (malabsorptive) or combined procedures does not appropriately reflect the current level of knowledge about early and weight-independent metabolic effects of these operations. Nowadays, most of the standard surgical interventions are being mostly referred to as metabolic operations. The focus when treating obese patients is gradually shifting from the primary goal of weight loss outcomes to the metabolic effects of the operations [125-137] \{levels 1,2\}. 
Table 4 (continued)

VII. Genitourinary system /reproductive health

Urinary incontinence

Menstrual irregularity

İnfertility

Hirsutism

Polycystic ovary disease

Miscarriage

Gestational diabetes

Hypertension

Preeclampsia

Macrosomia

Foetal distress

Malformation (i.e. neural tube defect)

Dystocia and primary caesarean section

VIII. Psychological and social consequences

Low self-esteem

Anxiety and depression

Stigmatisation

Discrimination in employment, college acceptance, job earning etc.

IX. Miscellaneous

Idiopathic intracranial hypertension

Proteinuria

Nephrotic syndrome

Skin infection

Lymphoedema

Complications from anaesthesia

Periodontal disease

\section{Treatment of Co-Morbidities}

Active treatment of obesity-related co-morbidities (table 4) should be integral part of the comprehensive management of the obese patients. Appropriate management of obesity complications in addition to weight management should include [37, 138] \{level 1,2\}:

- Management of dyslipidaemia

- Optimising glycaemic control in type 2 diabetics

- $\quad$ Normalising blood pressure in hypertension

- Management of pulmonary disorders, such as SAS

- Attention to pain control and mobility needs in osteoarthritis

- Management of psychosocial disturbances, including affective disorders, eating

disorders, low self-esteem and body image disturbance.

The presence of obesity and the effects that treatments have on body weight, body composition or metabolic status should be taken into account in the selection of the drugs used to treat obesity-related co-morbidities or even non-obesity-related diseases occurring in a patient with obesity. Drugs increasing body weight and/or with negative metabolic effects should be possibly avoided or substituted. Weight-losing and weight-neutral medications should be preferred [73]. Specific guidelines for the management of hypertension in obese patients [139] have been released by the EASO in conjunction with the European Society of Hypertension. 
Yumuk et al.: European Guidelines for Obesity Management in Adults

\section{Alternative Therapies}

Obesity treatment has often been unsuccessful. As a result, unorthodox and unproven treatments flourish and are often offered. There is insufficient evidence to recommend in favour of herbal medicines, dietary supplements or homoeopathy for obesity management in the obese person. Physicians should advise patients to follow evidence-based treatments and recommend treatments only where evidence of safety and efficacy has been established $\{\mathrm{RBP}\}$.

\section{Collaborating Centre for Obesity Management}

A comprehensive obesity management can only be accomplished by an appropriate obesity management team which is multidisciplinary and comprises different professionals who are able to tackle the different aspects of obesity and its related disorders. In accordance with this vision the EASO has developed a network of Collaborating Centres for Obesity Management. This European networking comprises education and training, research initiatives and contemporary obesity care [140].

\section{Conclusion}

Physicians have a responsibility to recognise obesity as a gateway disease and help patients with appropriate prevention and treatment schemes for obesity and its co-morbidities. Along with physicians all care givers have the same responsibility. Obesity care needs to be delivered by certified obesity experts in specialised and accredited obesity centres. Treatment should be based on good clinical care and evidence-based interventions and it should be individualised and multidisciplinary, focus on realistic goals, weight maintenance and prevention of weight regain. Everybody in the field, including the patients, should understand that, since obesity is a chronic disease, weight management will need to be lifelong.

\section{Appendix}

\section{Levels of Evidence and Grades of Recommendation}

The evidence for the guidance given is drawn from a number of systematic reviews listed in the references. The grading system is based upon the Scottish Intercollegiate Guidelines Network (SIGN), but has been simplified by amalgamating sub-categories of each level into a single criterion. No health-care system can provide treatment for all who are obese and overweight. Support groups, commercial and lay organisations, books and other media can provide useful help and support; the advice they give should conform to the principles of these guidelines (table 5) [141] \{RBP\}. 
Table 5. Levels of evidence, grades of recommendation and good practice points

Levels of evidence

$1 \quad 1++$ high-quality meta-analyses, systematic reviews of RCTs, or RCTs with a very low risk of bias

$1+\quad$ well-conducted meta-analyses, systematic reviews of RCTs, or RCTs with a low risk of bias

1- Meta-analyses, systematic reviews of RCTs, or RCTs with a high risk of bias

$22++$ high-quality systematic reviews of case-control or cohort or studies

$2+\quad$ high-quality case-control or cohort studies with a very low risk of confounding, bias, or chance and a high probability that the relationship is casual

2- well-conducted case control or cohort studies with a low risk of confounding, bias, or chance and a moderate probability that the relationship is casual

3 non-analytic studies, e.g. case reports, case series

4 expert opinion

Grades of recommendation

A at least one meta-analysis, systematic review, or RCT rated as $1++$, and directly applicable to the target population; or a systematic review of RCTs or a body of evidence consisting principally of studies rated as $1+$, directly applicable to the target population, and demonstrating overall consistency of results

B a body of evidence including studies rated as $2++$, directly applicable to the target population, and demonstrating overall consistency of results; or extrapolated evidence from studies rated as $1++$, or $1+$

C a body of evidence including studies rated as $2+$, directly applicable to the target population, and demonstrating overall consistency of results; or Extrapolated evidence from studies rated as 2++ evidence level 3 or 4; or extrapolated evidence from studies rated as $2+$

Good practice points

RBP recommended best practice based on the clinical experience of the guideline development group

\section{References}

1 Frühbeck G, Toplak H, Woodward E, Yumuk V, Maislos M, Oppert JM: Obesity: the gateway to ill health - an EASO position statement on a rising public health, clinical and scientific challenge in Europe. Obes Facts 2013; 6:117-120.

2 World Health Organization: Obesity and Overweight. WHO fact sheet $\mathrm{N}^{\circ}$ 311, Geneva, WHO, 2015. www.who. int/mediacentre/factsheets/fs311/en/ (last accessed November 30, 2015).

3 World Health Organization: World Health Statistics 2015. Geneva, WHO, 2015, pp 101-111. www.who.int/ gho/publications/world_health_statistics/2015/en/ (last accessed November 30, 2015).

4 Kelly T, Yang W, Chen CS, Reynolds K, He J: Global burden of obesity in 2005 and projections to 2030. Int J Obes (Lond) 2008;32:1431-1437.

5 Finer N: Medical consequences of obesity. Medicine 2015;43:88-93.

-6 Ng M, Fleming T, Robinson M, Thomson B, Graetz N, Margono C, Mullany EC, Biryukov S, Abbafati C, Abera SF, Abraham JP, Abu-Rmeileh NM, Achoki T, AlBuhairan FS, Alemu ZA, Alfonso R, Ali MK, Ali R, Guzman NA, Ammar W, Anwari P, Banerjee A, Barquera S, Basu S, Bennett DA, Bhutta Z, Blore J, Cabral N, Nonato IC, Chang JC, Chowdhury R, Courville KJ, Criqui MH, Cundiff DK, Dabhadkar KC, Dandona L, Davis A, Dayama A, Dharmaratne SD, Ding EL, Durrani AM, Esteghamati A, Farzadfar F, Fay DF, Feigin VL, Flaxman A, Forouzanfar MH, Goto A, Green MA, Gupta R, Hafezi-Nejad N, Hankey GJ, Harewood HC, Havmoeller R, Hay S, Hernandez L, Husseini A, Idrisov BT, Ikeda N, Islami F, Jahangir E, Jassal SK, Jee SH, Jeffreys M, Jonas JB, Kabagambe EK, Khalifa SE, Kengne AP, Khader YS, Khang YH, Kim D, Kimokoti RW, Kinge JM, Kokubo Y, Kosen S, Kwan G, Lai T, Leinsalu M, Li Y, Liang X, Liu S, Logroscino G, Lotufo PA, Lu Y, Ma J, Mainoo NK, Mensah GA, Merriman TR, Mokdad AH, Moschandreas J, Naghavi M, Naheed A, Nand D, Narayan KM, Nelson EL, Neuhouser ML, Nisar MI, Ohkubo T, Oti SO, Pedroza A, Prabhakaran D, Roy N, Sampson U, Seo H, Sepanlou SG, Shibuya K, Shiri R, Shiue I, Singh GM, Singh JA, Skirbekk V, Stapelberg NJ, Sturua L, Sykes BL, Tobias M, Tran BX, Trasande L, Toyoshima H, van de Vijver S, Vasankari TJ, Veerman JL, Velasquez-Melendez G, Vlassov VV, Vollset SE, Vos T, Wang C, Wang X, Weiderpass E, Werdecker A, Wright JL, Yang YC, Yatsuya H, Yoon J, Yoon SJ, Zhao Y, Zhou M, Zhu S, Lopez AD, Murray CJ, Gakidou E: Global, regional, and national prevalence of overweight and obesity in children and adults during 1980-2013: a systematic analysis for the Global Burden of Disease Study 2013. Lancet 2014;384:766-781. 
7 WHO: Obesity: Preventing and Managing the Global Epidemic. Report of a WHO Consultation. Geneva, WHO Technical Report Series 894, 2000.

8 James WP: The epidemiology of obesity: the size of the problem. J Intern Med 2008;263:336-352.

-9 Zhu S, Wang Z, Heshka S, Heo M, Faith MS, Heymsfield SB: Waist circumference and Obesity associated risk factors among whites in the third National Health and Nutrition Examination Survey: clinical action thresholds. Am J Clin Nutr 2002;76:743-749.

10 Alberti KG, Zimmet PZ, Shaw J: The metabolic syndrome - a new worldwide definition. Lancet 2005;366: 1059-1062.

11 Yanovski SZ, Yanovski JA: Obesity. N Engl J Med 2002;346:591-602.

12 Haslam DW, James WP: Obesity. Lancet 2005;366:1197-1209.

13 Farooqi S, O’Rahilly S: Genetics of obesity in humans. Endocr Rev 2006;27:710-718.

14 Kyrou I, Chrousos GP, Tsigos C: Stress, visceral obesity, and metabolic complications. Ann N Y Acad Sci 2006; 1083:77-110.

15 Branca F, Nikogosian H, Lobstein T (eds): The challenge of Obesity in the WHO European Region and the Strategies for Response: Summary. Copenhagen, WHO Regional Office for Europe, 2007.

16 Ailhaud G: Adipose tissue as a secretory organ: from adipogenesis to the metabolic syndrome. C R Biol 2006; 329:570-577.

17 Tilg H, Moschen AR: Adipocytokines: mediators linking adipose tissue, inflammation and immunity. Nat Rev Immunol 2006;6:772-783.

18 Buhmann H, le Roux CW, Bueter M: The gut brain axis in obesity. Best Pract Res Clin Gastroenterol 2014;28: 559-571.

19 Holtmann G, Talley NJ: The stomach brain axis. Best Pract Res Clin Gastroenterol 2014;28:967-979.

20 Gerard P: Gut microbiota and obesity. Cell Mol Life Sci 2015. DOI 10.1007/s00018-015-2061-5.

-21 Tilg H, Adolph TE: Influence of the human intestinal microbiome on obesity and metabolic dysfunction. Curr Opin Pediatr 2015:27:496-501.

-22 Cypess AM, Lehman S, Williams G, Tal I, Rodman D, Goldfine AB, Kuo FC, Palmer EL, Tseng Y-H, Doria A, Kolodny GM, Kahn R: Identification and importance of brown adipose tissue in adult humans. N Engl J Med 2009;360:1509-1517.

-23 Virtanen KA, Lidell ME, Orava J, Heglind M, Westergren R, Niemi T, Taittonen M, Laine J, Savisto N-J, Enerback S, Nuutila P: Functional brown adipose tissue in healthy adults. N Engl J Med 2009;360:1518-1525.

24 Butler PW, Mentuccia D, Celi FS: Stimulating brown fat: a potential future therapeutic approach for obesity and insulin resistance? Heart Metab 2010;48:19-22.

25 National Institutes of Health: The Practical Guide: Identification, Evaluation, and Treatment of Overweight and Obesity in Adults. NHLBI Obesity Education Initiative Expert Panel on the Identification, Evaluation, and Treatment of Overweight and Obesity in Adults. Bethesda, NIH, 2000. www.nhlbi.nih.gov/files/docs/guidelines/prctgd_c.pdf (last accessed November 30, 2015).

-26 National Institute for Health and care Excellence: Obesity: Identification, Assessment and Management of Overweight and Obesity in Children, Young People and Adults. London, NICE, 2014. www.nice.org.uk/ guidance/cg189 (last accessed November 30, 2015).

27 Kushner RF: Clinical assessment and management of adult obesity. Circulation 2012;126:2870-2877.

28 Silver HJ, Welch EB, Avison MJ, Niswender KD: Imaging body composition in obesity and weight loss: challenges and opportunities. Diabetes Metab Syndr Obes 2010;3:337-347.

29 Bolanowski M, Nilsson BE: Assessment of human body composition using dual-energy x-ray absorptiometry and bioelectrical impedance analysis. Med Sci Monit 2001;7:1029-1033.

-30 Cornier M-A, Després J-P, Davis N, Grossniklaus DA, Klein S, Lamarche B, Lopez-Jimenez F, Rao G, St-Onge M-P, Towfighi A, Poirier P; on behalf of the American Heart Association Obesity Committee of the Council on Nutrition, Physical Activity and Metabolism, Council on Arteriosclerosis, Thrombosis and Vascular Biology, Council on Cardiovascular Disease in the Young, Council on Cardiovascular Radiology and Intervention, Council on Cardiovascular Nursing, Council on Epidemiology and Prevention, Council on the Kidney in Cardiovascular Disease, and Stroke Council: Assessing adiposity: a scientific statement from the American Heart Association. Circulation 2011;124:1996-2019.

-31 Yumuk V, Frühbeck G, Oppert JM, Woodward E, Toplak H, for the Executive Committee of the European Association for the Study of Obesity: An EASO position statement on multidisciplinary obesity management in adults. Obes Facts 2014;7:96-101.

-32 Slentz CA, Duscha BD, Johnson JL, Ketchum K,Aiken LB, Samsa GP, Houmard JA, Bales CW, Kraus WE: Effects of the amount of exercise on body weight, body composition, and measures of central obesity: STRRIDE - a randomized controlled study. Arch Intern Med 2004;164:31-39.

33 Pietrobelli A, Heymsfield SB: Establishing body composition in obesity. J Endocrinol Invest 2002;25:884-892.

-34 Knowler WC, Barrett-Connor E, Fowler SE, Hamman RF, Lachin JM, Walker EA, Nathan DM; Diabetes Prevention Program Research Group: Reduction in the incidence of type 2 diabetes with lifestyle intervention or metformin. N Engl J Med 2002;346:393-403.

-35 Blundell JE, Dulloo AG, Salvador J, Frühbeck G, on behalf of the EASO SAB Working Group on BMI: Beyond BMI - phenotyping the obesities. Obes Facts 2014;7:322-328. 
Yumuk et al.: European Guidelines for Obesity Management in Adults

-36 Schwarz PE, Lindström J, Kissimova-Scarbeck K,Szybinski Z, Barengo NC, Peltonen M, Tuomilehto J: The European perspective of type 2 diabetes prevention: diabetes in Europe - prevention using lifestyle, physical activity and nutritional intervention (DE-PLAN) project. Exp Clin Endocrinol Diabetes 2008;116:167-172.

-37 Hainer V, Toplak H, Mitrakou A: Treatment modalities of obesity: What fits whom? Diabetes Care 2008; 31(suppl 2):S269-S277.

38 Sampsel S, May J: Assessment and management of obesity and comorbid conditions. Dis Manag 2007;1:252265.

39 Jensen MD, Ryan DH, Apovian CM, Ard JD, Comuzzie AG, Donato KA, Hu FB, Hubbard VS, Jakicic JM, Kushner RF, Loria CM, Millen BE, Nonas CA, Pi-Sunyer FX, Stevens J, Stevens VJ, Wadden TA, Wolfe BM, Yanovski SZ, Jordan HS, Kendall KA, Lux LJ, Mentor-Marcel R, Morgan LC, Trisolini MG, Wnek J, Anderson JL, Halperin JL, Albert NM, Bozkurt B, Brindis RG, Curtis LH, DeMets D, Hochman JS, Kovacs RJ, Ohman EM, Pressler SJ, Sellke FW, Shen WK, Smith SC Jr, Tomaselli GF; American College of Cardiology/American Heart Association Task Force on Practice Guidelines; Obesity Society: 2013 AHA/ACC/TOS Guideline for the Management of Overweight and Obesity in Adults: a report of the American College of Cardiology/American Heart Association Task Force on Practice Guidelines and The Obesity Society. Circulation 2014;129(suppl 2): S102-S138. Erratum in Circulation 2014;129(suppl 2):S139-140.

40 World Health Organization: Obesity: Preventing and Managing the Global Epidemic. Report of a WHO Consultation (WHO Technical Report Series 894). Geneva, WHO, 1998. www.who.int/nutrition/publications/obesity/ WHO_TRS_894/en/ (last accessed November 30, 2015).

41 Lahti-Koski M, Männistö S, Pietinen P, Vartiainen E: Prevalence of weight cycling and its relation to health indicators in Finland. Obes Res 2005;13:333-341.

-42 Marchesini G, Cuzzolaro M, Mannucci E, DalleGrave R, Gennaro M, Tomasi F, Barantani EG, Melchionda N; QUOVADIS Study Group: Weight cycling in treatment-seeking obese persons: data from the QUOVADIS study. Int J Obes Relat Metab Disord 2004;28:1456-1462.

43 Anderson JW, Konz EC, Frederich RC, Wood CL: Long-term weight-loss maintenance: a meta-analysis of US studies. Am J Clin Nutr 2001;74:579-584..

44 Christie D, Channon S: The potential for motivational interviewing to improve outcomes in the management of diabetes and obesity in paediatric and adult populations: a clinical review. Diabetes, Obes Metab 2014;16: 381-387.

-45 Armstrong MJ, Mottershead TA, Ronksley PE, Sigal RJ, Campbell TS, Hemmelgarn BR: Motivational interviewing to improve weight loss in overweight and/or obese patients: a systematic review and meta-analysis of randomized controlled trials. Obes Rev 2011;12:709-723.

46 Dansinger ML, Tatsioni A, Wong JB, Chung M, Balk EM: Meta-analysis: the effect of dietary counseling for weight loss. Ann Intern Med 2007;147:41-50.

-47 Astrup A, Grunwald GK, Melanson EL, Saris WH, Hill JO: The role of low-fat diets in body weight control: a meta-analysis of ad libitum dietary intervention studies. Int J Obes Relat Metab Disord 2000;24:1545-1552.

-48 Pirozzo S, Summerbell C, Cameron C, Glasziou P: Advice on low-fat diets for obesity. Cochrane Database Syst Rev 2002;2:CD003640.

49 Sacks FM, Bray GA, Carey VJ, Smith SR, Ryan DH, Anton SD, McManus K, Champagne CM, Bishop LM, Laranjo N, Leboff MS, Rood JC, de Jonge L, Greenway FL, Loria CM, Obarzanek E, Williamson DA: Comparison of weightloss diets with different compositions of fat, protein, and carbohydrates. N Engl J Med 2009;360:859-873.

50 Larsen TM, Dalskov S-M, van Baak M, Jebb SA, Papadaki A, Pfeiffer AFH, Martinez JA, Handjieva-Darlenska T, Kunešová M, Pihlsgård M, Stender S, Holst C, Saris WHM, Astrup A, for the Diet, Obesity, and Genes (Diogenes) Project: Diets with high or low protein content and glycemic index for weight-loss maintenance. N Engl J Med 2010;363:2102-2113.

51 Shai I, Schwarzfuchs D, Henkin Y, Shahar DR, Witkow S, Greenberg I, Golan R, Fraser D, Bolotin A, Vardi H, Tangi-Rozental O, Zuk-Ramot R, Sarusi B, Brickner D, Schwartz Z, Sheiner E, Marko R, Katorza E, Thiery J, Fiedler GM, Bluher M, Stumvoll M, Stampfer MJ, for the Dietary Intervention Randomized Controlled Trial (DIRECT) Group: Weight loss with a low-carbohydrate, Mediterranean, or low-fat diet. N Engl J Med 2008;359: 229-241.

52 Dernini S, Berry EM: Mediterranean diet: from a healthy diet to a sustainable dietary pattern. Front Nutr 2015; 2:1-6.

-53 Estruch R, Ros E, Salas-Salvadó J, Covas M-I, Corella D, Arós F, Gómez-Gracia E, Ruiz-Gutiérrez V, Fiol M, Lapetra J, Lamuela-Raventos RM, Serra-Majem L, Pintó X, Basora J, Muñoz MA, Sorlí JV, Martínez JA, MartínezGonzález MA, for the PREDIMED Study Investigators: Primary prevention of cardiovascular disease with a Mediterranean diet. N Engl J Med 2013;368:1279-1290.

54 Ayyad C, Andersen T: Long-term efficacy of dietary treatment of obesity: a systematic review of studies published between 1931 and 1999. Obes Rev 2000;1:113-119.

55 Rössner S: Treatment: Diet; in Bjorntorp P(ed): International Textbook of Obesity. Sussex, Wiley \& Sons, 2001, pp 441-449.

Dubnov-Raz G, Berry EM. The dietary treatment of obesity. Endocrinol Metab Clin N Am 2008;37:873-886.

57 Tsai AG, Wadden TA: The evolution of very-low-calorie diets: an update and meta-analysis. Obesity (Silver Spring) 2006;14:1283-1293.

58 Heymsfield SB, van Mierlo CA, van der Knaap HC,Heo M, Frier HI: Weight management using a meal replacement strategy: meta and pooling analysis from six studies. Int J Obes Relat Metab Disord 2003;27:537-549. 
Yumuk et al.: European Guidelines for Obesity Management in Adults and/or resistance training on body mass and fat mass in overweight or obese adults. J Appl Physiol 2012;113: 1831-1837.

-61 Geliebter A, Christopher N, Ochner CN, Dambkowski CL, Hashim SA: Obesity-related hormones and metabolic risk factors: a randomized trial of diet plus either strength or aerobic training versus diet alone in overweight participants. J Diabetes Obes 2015;1:1-7.

-62 Poirier P, Després JP: Exercise in weight management of obesity. Cardiol Clin 2001;19:459-470.

63 Kay SJ, Fiatarone Singh MA: The influence of physical activity on abdominal fat: a systematic review of the literature. Obes Rev 2006; 7:183-200.

-64 Lee S, Kuk JL, Davidson LE, Hudson R, Kilpatrick K, Graham TE, Ross R: Exercise without weight loss is an effective strategy for obesity reduction in obese individuals with and without type 2 diabetes. J Appl Physiol 2005;99:1220-1225.

65 Ross R, Janssen I, Dawson J, Kungl AM, Kuk JL, Wong SL, Nguyen-Duy TB, Lee S, Kilpatrick K, Hudson R: Exercise-induced reduction in obesity and insulin resistance in women: a randomized controlled trial. Obes Res 2004;12:789-798.

66 Swift DL, Johannsen NM, Lavie CJ, Earnest CP, Church TS: The role of exercise and physical activity in weight loss and maintenance. Prog Cardiovasc Dis 2014;56:441-447.

-67 Jakicic JM, Otto AD: Physical activity considerations for the treatment and prevention of obesity. Am J Clin Nutr 2005;82(suppl 1): 226S-229S.

68 Sharma M: Behavioural interventions for preventing and treating obesity in adults. Obes Rev 2007;8:441-449.

-69 Lang A, Froelicher ES: Management of overweight and obesity in adults: behavioral intervention for long-term weight loss and maintenance. Eur J Cardiovasc Nurs 2006;5:102-114.

70 Moffitt R, Haynes A, Mohr P: Treatment beliefs and preferences for psychological therapies for weight management. J Clin Psychol 2015;71:584-596.

71 Toplak H, Woodward E, Yumuk V, Oppert JM, Halford JCG, Frühbeck G: 2014 EASO position statement on the use of anti-obesity drugs. Obes Facts 2015;8:166-174.

-72 Pucci A, Finer N: New medications for treatment of obesity: metabolic and cardiovascular effects. Can J Cardiol 2015;31:142-152.

73 Apovian CM, Aronne LJ, Bessesen DH, McDonnell ME, Murad MH, Pagotto U, Ryan DH, Still CD: Pharmacological management of obesity: an endocrine society clinical practice guideline. J Clin Endocrinol Metab 2015;100: 342-362.

74 Bray GA: Medical treatment of obesity: the past, the present and the future. Best Pract Res Clin Gastroenterol 2014;28:665-684.

-75 Torgerson JS, Hauptman J, Boldrin MN, Sjöström L: Xenical in the Prevention of Diabetes in Obese Subjects (XENDOS) study: a randomized study of orlistat as an adjunct to lifestyle changes for the prevention of type 2 diabetes in obese patients. Diabetes Care 2004;27:155-161.

-76 Toplak H, Ziegler O, Keller U, Hamann A, Godin C, Wittert G, Zanella MT, Zúñiga-Guajardo S, Van Gaal L: X-PERT: weight reduction with orlistat in obese subjects receiving a mildly or moderately reduced-energy diet: early response to treatment predicts weight maintenance. Diabetes Obes Metab 2005;7:699-708.

77 Ballinger A, Peikin SR: Orlistat: its current status as an anti-obesity drug. Eur J Pharmacol 2002;440:109-117. Thomsen WJ, Grottick AJ, Menzaghi F, Reyes-Saldana H, Espitia S, Yuskin D, Whelan K, Martin M, Morgan M Chen W, Al-Shamma H, Smith B, Chalmers D, Behan D: Lorcaserin: a novel selective human 5-hydroxytryptamine 2C agonist: in vitro and in vivo pharmacological characterization. J Pharmacol Exp Ther 2008;325: 577-587.

-79 Chan EW, He Y, Chui CS, Wong AY, Lau WC, Wong IC: Efficacy and safety of lorcaserin in obese adults: a metaanalysis of 1-year randomized controlled trials (RCTs) and narrative review on short-term RCTs. Obes Rev $2013 ; 14: 383-392$

-80 Fujioka K: Safety and tolerability of medications approved for chronic weight management. Obesity (Silver Spring) 2015;23(suppl 1):S7-S11.

-81 Smith SR, Weissman NJ, Anderson CM, Sanchez M, Chuang E, Stubbe S, Bays H, Shanahan WR; Behavioral Modification and Lorcaserin for Overweight and Obesity Management (BLOOM) Study Group: Multicenter, placebo controlled trial of lorcaserin for weight management. N Engl J Med 2010;363:245-256.

-82 O’Neil PM, Smith SR, Weissman NJ, Fidler MC, Sanchez M, Zhang J, Raether B, Anderson CM, Shanahan WR: Randomized placebo controlled clinical trial of lorcaserin for weight loss in type 2 diabetes mellitus: the BLOOM-DM study. Obesity (Silver Spring) 2012;20:1426-1436.

-83 Fidler MC, Sanchez M, Raether B, Weissman NJ, Smith SR, Shanahan WR, Anderson CM; BLOSSOM Clinical Trial Group: A one-year randomized trial of lorcaserin for weight loss in obese and overweight adults: the BLOSSOM trial. J Clin Endocrinol Metab 2011;96:3067-3077.

84 Weissman NJ, Sanchez M, Koch GG, Smith SR, Shanahan WR, Anderson CM: Echocardiographic assessment of cardiac valvular regurgitation with lorcaserin from analysis of 3 phase 3 clinical trials. Circ Cardiovasc Imaging 2013;6:560-567

-85 Shukla AP, Kumar RB, Aronne LJ: Lorcaserin HCl for the treatment of obesity. Expert Opin Pharmacother 2015; 15:1-8. 
Yumuk et al.: European Guidelines for Obesity Management in Adults

86 ClinicalTrials.gov: A study to evaluate the effect of long-term treatment with BELVIQ (lorcaserin $\mathrm{HCl}$ ) on the incidence of major adverse cardiovascular events and conversion to type 2 diabetes mellitus in obese and overweight subjects with cardiovascular disease or multiple cardiovascular risk factors (CAMELLIA-TIMI). https://clinicaltrials.gov/ct2/show/NCT02019264 (last accessed November 30, 2015).

87 Singh J, Kumar R: Phentermine-topiramate: First combination drug for obesity. Int J Appl Basic Med Res 2015; 5:157-158.

88 Allison DB, Gadde KM, Garvey WT, Peterson CA, Schwiers ML, Najarian T, Tam PY, Troupin B, Day WW: Controlled-release phentermine/topiramate in severely obese adults: a randomized controlled trial (EQUIP). Obesity (Silver Spring) 2012;20:330-342.

89 Gadde KM, Allison DB, Ryan DH, Peterson CA, Troupin B, Schwiers ML, Day WW: Effects of low-dose, controlled release, phentermine plus topiramate combination on weight and associated comorbidities in overweight and obese adults (CONQUER): a randomised, placebo-controlled, phase 3 trial. Lancet 2011;377:1341-1352.

90 Garvey WT, Ryan DH, Look M, Gadde KM, Allison DB, Peterson CA, Schwiers M, Day WW, Bowden CH: Two-year sustained weight loss and metabolic benefits with controlled-release phentermine/topiramate in obese and overweight adults (SEQUEL): a randomized, placebo controlled, phase 3 extension study. Am J Clin Nutr 2012; 95:297-308.

91 Aronne LJ, Wadden TA, Peterson C, Winslow D, Odeh S, Gadde KM: Evaluation of phentermine and topiramate versus phentermine/topiramate extended-release in obese adults. Obesity (Silver Spring) 2013;21:21632171.

-92 Jordan J, Astrup A, Engeli S, Narkiewicz K, Day WW, Finer N: Cardiovascular effects of phentermine and topiramate: a new drug combination for the treatment of obesity. J Hypertens 2014;32:1178-1188.

93 VIVUS Reports Topline Findings from FORTRESS. (media release on the internet). 21 December, 2011. http:// ir.vivus.com/releasedetail.cfm?ReleaseID=634920 (last accessed November 30, 2015).

-94 Fujioka K: Sustained-release naltrexone/bupropion: a novel pharmacologic approach to obesity and food craving. US Endocrinology 2014;10:53-58.

95 Greenway FL, Fujioka K, Plodkowski RA, Mudaliar S, Guttadauria M, Erickson J, Kim DD, Dunayevich E; COR-I Study Group: Effect of naltrexone plus bupropion on weight loss in overweight and obese adults (COR-I): a multicentre, randomised, double-blind, placebo-controlled, phase 3 trial. Lancet 2010;376:595-605.

-96 Apovian CM, Aronne L, Rubino D, Still C, Wyatt H, Burns C, Kim D, Dunayevich E COR-II Study Group: A randomized, phase 3 trial of naltrexone SR/bupropion SR on weight and obesity-related risk factors (COR-II). Obesity (Silver Spring) 2013;21:935-943.

97 Wadden TA, Foreyt JP, Foster GD, Hill JO, Klein S, O’Neil PM, Perri MG, Pi-Sunyer FX, Rock CL, Erickson JS, Maier HN, Kim DD, Dunayevich E: Weight loss with naltrexone SR/bupropion SR combination therapy as an adjunct to behavior modification: the COR-BMOD trial. Obesity (Silver Spring) 2011;19:110-120.

-98 Hollander P, Gupta AK, Plodkowski R, Greenway F, Bays H, Burns C, Klassen P, Fujioka K; for The COR-Diabetes Study Group: Effects of naltrexone sustained-release/bupropion sustained-release combination therapy on body weight and glycemic parameters in overweight and obese patients with type 2 diabetes. Diabetes Care 2013;36:4022-4029.

99 ClinicalTrials.gov: Cardiovascular Outcomes Study of Naltrexone SR/Bupropion SR in Overweight and Obese Subjects with Cardiovascular Risk Factors (The Light Study). https://clinicaltrials.gov/ct2/show/record/ NCT01601704 (last accessed November 30, 2015).

100 Holst JJ: Incretin hormones and the satiation signal. Int J Obes (Lond) 2013;37:1161-1168.

-101 Astrup A, Carraro R, Finer N, Harper A, Kunesova M, Lean ME, Niskanen L, Rasmussen MF, Rissanen A, Rössner S, Savolainen MJ, Van Gaal L; NN8022-1807 Investigators: Safety, tolerability and sustained weight loss over 2 years with the once-daily human GLP-1 analog, liraglutide. Int J Obes (Lond) 2012;36:843-854.

102 Vilsboll T, Christensen M, Junker AE, Knop FK, Gluud LL: Effects of glucagon-like peptide-1 receptor agonists on weight loss: systematic review and meta-analyses of randomised controlled trials. BMJ 2012;344:d7771.

103 Astrup A, Rossner S, Van Gaal L Rissanen A, Niskanen L, Al Hakim M, Madsen J, Rasmussen MF, Lean ME; NN8022-1807 Study Group: Effects of liraglutide in the treatment of obesity: a randomised, double-blind, placebo-controlled study. Lancet 2009;374:1606-1616.

104 Kim SH, Abbasi F, Lamendola C, Liu A, Ariel D, Schaaf P, Grove K, Tomasso V, Ochoa H, Liu YV, Chen YD, Reaven G: Benefits of liraglutide treatment in overweight and obese older individuals with prediabetes. Diabetes Care 2013;36:3276-3282.

105 Wadden TA, Hollander P, Klein S Niswender K, Woo V, Hale PM, Aronne L; NN8022-1923 Investigators: Weight maintenance and additional weight loss with liraglutide after low-calorie-diet-induced weight loss: the SCALE Maintenance randomized study. Int J Obes (Lond) 2013;37:1443-1451.

106 Pi-Sunyer X, Astrup A, Fujioka K, Greenway F, Halpern A, Krempf M, Lau DCW, le Roux CW, Ortiz RV, BjornJensen C, Wilding JPH for the SCALE Obesity and Prediabetes NN8022-1839 Study Group: A randomized controlled trial of $3.0 \mathrm{mg}$ liraglutide in weight management. N Engl J Med 2015;373:11-22.

107 ClinicalTrials.gov: Liraglutide Effect and Action in Diabetes: Evaluation of Cardiovascular Outcome Results - A Long Term Evaluation (LEADER ${ }^{\circledR}$ ). https://clinicaltrials.gov/ct2/show/NCT01179048 (last accessed November 30, 2015).

108 Marso SP, Poulter NR, Nissen SE, Nauck MA, Zinman B, Daniels GH, Pocock S, Steinberg WM, Bergenstal RM, Mann JF, Ravn LS, Frandsen KB, Moses AC, Buse JB: Design of the liraglutide effect and action in diabetes: evaluation of cardiovascular outcome results (LEADER) trial. Am Heart J 2013;166:823-830. 
109 Daniels GH, Hegedüs L, Marso SP, Nauck MA, Zinman B, Bergenstal RM, Mann JFE, Karsbøl JD, Moses AC, Buse JB, Tuttle RM on behalf of the LEADER trial investigators: LEADER 2: baseline calcitonin in 9340 people with type 2 diabetes enrolled in the Liraglutide Effect and Action in Diabetes: Evaluation of cardiovascular outcome Results (LEADER) trial: preliminary observations. Diabetes Obes Metab 2015;17:477-486.

110 Lean ME, Carraro R, Finer N, Hartvig H, Lindegaard ML, Rössner S, Van Gaal L, Astrup A; NN8022-1807 Investigators: Tolerability of nausea and vomiting, and associations with weight loss, in a randomized trial of liraglutide in obese, non-diabetic adults. Int J Obes (Lond) 2013;38:689-697.

111 Pories WJ: Bariatric surgery: risks and rewards. J Clin Endocrinol Metab 2008;93(suppl 1):S89-S96.

112 Sjöström L: Review of the key results from the Swedish Obese Subjects (SOS) trial - a prospective controlled intervention study of bariatric surgery. J Intern Med 2013;273:219-234.

113 Berrington de Gonzalez A, Hartge P, Cerhan JR, Flint AJ, Hannan L, MacInnis RJ, Moore SC, Tobias GS, AntonCulver H, Freeman LB, Beeson WL, Clipp SL, English DR, Folsom AR, Freedman DM, Giles G, Hakansson N,Henderson KD, Hoffman-Bolton J, Hoppin JA, Koenig KL, Lee IM, Linet MS, Park Y, Pocobelli G, Schatzkin A, Sesso HD, Weiderpass E, Willcox BJ, Wolk A, Zeleniuch-Jacquotte A, Willett WC, Thun MJ: Body-mass index and mortality among 1.46 million white adults. N Engl J Med 2010;363:2211-2219.

114 Flegal KM, Kit BK, Orpana H, Graubard BI: Association of all-cause mortality with overweight and obesity using standard body mass index categories: a systematic review and meta-analysis. JAMA 2013;309:71-82.

115 Neovius M, Narbro K, Keating C, Peltonen M, Sjöholm K, Agren G, Sjöström L, Carlsson L: Health care use during 20 years following bariatric surgery. JAMA 2012;308:1132-1141.

116 Fried M, Yumuk Y, Oppert JM, Scopinaro N, Torres AJ, Weiner R, Yashkov Y, Frühbeck G: Interdisciplinary European guidelines on metabolic and bariatric surgery. Obes Facts 2013;6:449-468.

117 Buchwald H, Estok R, Fahrbach K, Banel D, Jensen MD, Pories WJ, Bantle JP, Sledge I: Weight and type 2 diabetes after bariatric surgery: systemic review and meta-analysis. Am J Med 2009;122:248-256.

118 Hofsø D, Nordstrand N, Johnson LK, Karlsen TI, Hager H, Jenssen T, Bollerslev J, Godang K, Sandbu R, Røislien J, Hjelmesaeth J: Obesity-related cardiovascular risk factors after weight loss: a clinical trial comparing gastric bypass surgery and intensive lifestyle intervention. Eur J Endocrinol 2010;163; 735-745.

119 Hofsø D, Jenssen T, Bollerslev J Ueland T, Godang K, Stumvoll M, Sandbu R, Røislien J, Hjelmesæth J: Beta cell function after weight loss: a clinical trial comparing gastric bypass surgery and intensive lifestyle intervention. Eur J Endocrinol 2011;164:231-238.

120 Schauer PR, Bhatt DL, Kirwan JP, Wolski K, Brethauer SA, Navaneethan SD, Aminian A, Pothier CE, Kim ESH, Nissen SE, Kashyap SR for the STAMPEDE Investigators: Bariatric surgery versus intensive medical therapy for diabetes - 3-year outcomes. N Engl J Med 2014;370:2002-2013.

121 DeMaria EJ: Bariatric surgery for morbid obesity. N Engl J Med 2007;356:2176-2183.

122 Sauerland S, Angrisani L, Belachew M, Chevallier JM, Favretti F, Finer, N Fingerhut A, Garcia Caballero M, Guisado Macias JA, Mittermair R, Morino M, Msika S, Rubino F, Tacchino R, Weiner R, Neugebauer EA; European Association for Endoscopic Surgery: Obesity surgery: evidence based guidelines of the EAES. Surg Endosc 2005; 19:200-221.

123 Ferraro DR: Preparing patients for bariatric surgery - the clinical considerations. Clin Rev 2004;14:57-63.

124 Reoch J, Mottillo S, Shimony A, Filion KB, Christou NV, Joseph L, Poirier P, Eisenberg MJ: Safety of laparoscopic vs open bariatric surgery: a systematic review and meta-analysis. Arch Surg 2011;146:1314-1322.

-125 Korner J, Inabnet W, Febres G, Conwell IM, McMahon DJ, Salas R, Taveras C, Schrope B, Bessler M: Prospective study of gut hormone and metabolic changes after adjustable gastric banding and Roux-en-Y gastric bypass. Int J Obes (Lond) 2009;33:786-795.

126 Laferrere B, Teixeira J, McGinty J, Tran H, Egger JR, Colarusso A, Kovack B, Bawa B, Koshy N, Lee H, Yapp K, Olivan B: Effect of weight loss by gastric bypass surgery versus hypocaloric diet on glucose and incretin levels in patients with type 2 diabetes. J Clin Endocrinol Metab 2008;93:2479-2485.

127 Bose M, Teixeira J, Olivan B, Bawa B, Arias S, Machineni S, Pi-Sunyer FX, Scherer PE, Laferrère B: Weight loss and incretin responsiveness improve glucose control independently after gastric bypass surgery. J Diabetes 2010;2:47-55.

128 Vidal J, Ibarzabal A, Romero F, Delgado S, Momblán D, Flores L, Lacy A: Type 2 diabetes mellitus and the metabolic syndrome following sleeve gastrectomy in severely obese subjects. Obes Surg 2008;18:1077-1082.

129 Leslie DB, Dorman RB, Serrot FJ, Swan TW, Kellogg TA, Torres-Villalobos G, Buchwald H, Slusarek BM, Sampson BK, Bantle JP, Ikramuddin S: Efficacy of the Roux-en-Y gastric bypass compared to medically managed controls in meeting the American Diabetes Association composite end point goals for management of type 2 diabetes mellitus. Obes Surg 2012;22:367-374.

130 Carlsson LM, Peltonen M, Ahlin S, Anveden Å, Bouchard C, Carlsson B, Jacobson P, Lönroth H, Maglio C, Näslund I, Pirazzi C, Romeo S, Sjöholm K, Sjöström E, Wedel H, Svensson PA, Sjöström L: Bariatric surgery and prevention of type 2 diabetes in Swedish obese subjects. N Engl J Med 2012;367:695-704.

131 Arterburn DE, Bogart A, Sherwood NE, Sidney S, Coleman KJ, Haneuse S, O'Connor PJ, Theis MK, Campos GM, McCulloch D, Selby J: A multisite study of long-term remission and relapse of type 2 diabetes mellitus following gastric bypass. Obes Surg 2013;23:93-102.

132 Laferrere B: Effect of gastric bypass surgery on the incretins. Diabetes Metab 2009;35:513-517.

133 Kashyap SR, Daud S, Kelly KR, Gastaldelli A, Win H, Brethauer S, Kirwan JP, Schauer PR: Acute effects of gastric bypass versus gastric restrictive surgery on beta cell function and insulinotropic hormones in severely obese patients with type 2 diabetes. Int J Obes (Lond) 2010;34:462-471. 
Yumuk et al.: European Guidelines for Obesity Management in Adults

134 Peterli R, Wolnerhanssen B, Peters T, Devaux N, Kern B, Christoffel-Courtin C, Drewe J, von Flüe M, Beglinger C: Improvement in glucose metabolism after bariatric surgery: comparison of laparoscopic Roux-en-Y gastric bypass and laparoscopic sleeve gastrectomy: a prospective randomized trial. Ann Surg 2009;250:234-241.

135 Mingrone G, Castagneto-Gissey L: Mechanisms of early improvement/resolution of type 2 diabetes after bariatric surgery. Diabetes Metab 2009;35:518-523.

136 Briatore L, Salani B, Andraghetti G, Maggi D, Adami GF, Scopinaro N, Cordera R: Beta-cell function improvement after biliopancreatic diversion in subjects with type 2 diabetes and morbid obesity. Obesity (Silver Spring) 2010;18:932-936.

137 Briatore L, Salani B, Andraghetti G, Danovaro C, Sferrazzo E, Scopinaro N, Adami GF, Maggi D, Cordera R: Restoration of acute insulin response in T2DM subjects 1 month after biliopancreatic diversion. Obesity (Silver Spring) 2008;16:77-81.

138 Sampsel S, May J: Assessment and management of obesity and comorbid conditions. Dis Manag 2007;1:252265.

139 Jordan J, Yumuk V, Schlaich M, Nilsson PM, Zahorska-Markiewicz B, Grassi G, Schmieder RE, Engeli S, Finer N: Joint statement of the European Association for the Study of Obesity and the European Society of Hypertension: obesity and difficult to treat arterial hypertension. J Hypertens 2012;30:1047-1055.

140 Tsigos C, Hainer V, Basdevant A, Finer N, Mathus-Vliegen E, Micic D, Maislos M, Roman G, Schutz Y, Toplak H, Yumuk V, Zahorska-Markiewicz B; for the Obesity Management Task Force of the European Association for the Study of Obesity: Criteria for EASO-collaborating centres for obesity management. Obes Facts 2011;4: 329-333.

141 Scottish Intercollegiate Guidelines Network: Obesity in Scotland. Integrating Prevention with Weight Management. A National Clinical Guideline Recommended for Use in Scotland. Edinburgh, Scottish Intercollegiate Guidelines Network, 1996. 


\section{Erratum}

In the article by Yumuk V, Tsigos C, Fried M, Schindler K, Busetto L, Micic D, Toplak H, for the Obesity Management Task Force of the European Association for the Study of Obesity, entitled 'European Guidelines for Obesity Management in Adults' [Obes Facts 2015;8:402-424, DOI:10.1159/000442721], figure 2 was not correctly given.

\section{Clinical care pathway for overweight and obese adults}

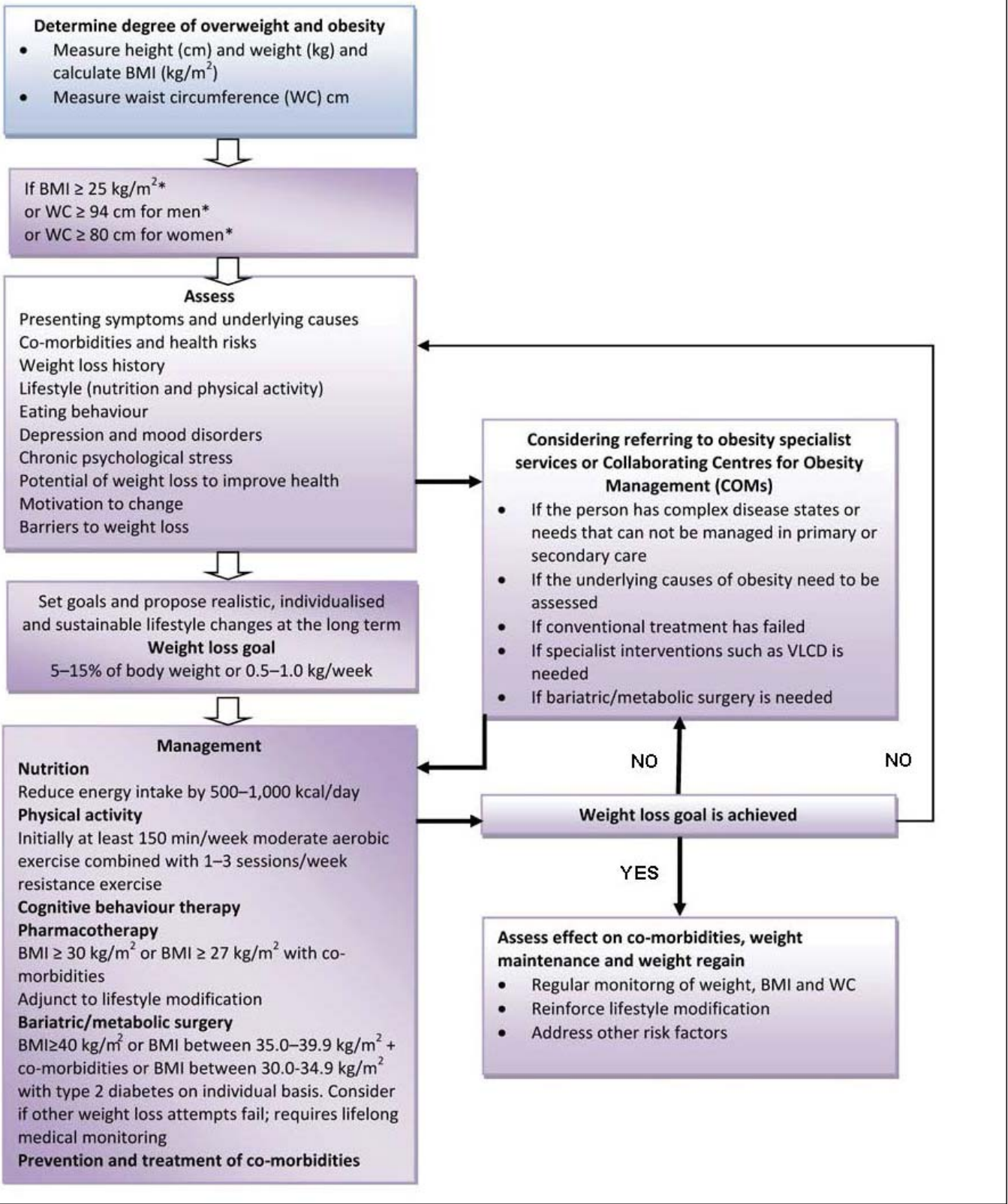

Fig. 2. Algorithm for the assessment and stepwise management of overweight and obese adults. *BMI and WC cut-off points are different for some ethnic groups (see text). 